\title{
COMMUNITY-BASED TOURISM AND NETWORKS: AN ANALYSIS OF THE COLLABORATIVE RELATIONSHIPS IN THE TUCUM NETWORK, BRAZIL
}

\author{
Débora Goes Urano \\ Mestre em Turismo pela Universidade Federal do Rio Grande do Norte - PPGTUR/UFRN \\ Doutoranda do Programa de Pós Graduação em Turismo \\ da Universidade Federal do Rio Grande do Norte (PPGTUR/UFRN). \\ Natal / RN. Brasil \\ deboragurano@gmail.com
}

Wilker Ricardo de Mendonça Nóbrega Doutor em Ciências Sócio Ambientais pela Universidade Federal do Pará - NAEA / UFPA. Professor e pesquisador da Universidade Federal do Rio Grande do Norte (UFRN). Natal / RN. Brasil

Abstract wilkernobrega@yahoo.com.br

Objective: The paper aims to analyze the collaborative relationships within the Community Tourism Network of Ceará (Tucum Network), based on the levels of collaboration of Tolkach, King \& Pearlman (2013).

Methodology: Data was collected through documentary research and interviews with 62 actors. The research approach was qualitative, and data was analyzed using an adaptation of content analysis.

Originality/Relevance: The research is relevant because studies on community-based tourism networks focus mainly on proposing a network approach to strengthen community-based tourism initiatives, or on the role, structures, and organizations of these networks. There is little emphasis on understanding the collaborative relationships between the network's nodes, and the impacts of these relationships on the development of tourism, and on the networks' success.

Main Results: The results showed that the first level of collaboration is influenced both by the formation of community ties and by external factors. At the second level, the role of non-governmental organizations was identified as a support link between the various communities, as they stimulate the connections between community-based tourism initiatives. Finally, at the third level, the process of collaboration between Network members is weakened, mainly due to barriers in the communication process and lack of resources faced by the Network and the communities, causing connections to be disjointed.

Theoretical/Methodological Contributions: A deeper understanding of how these collaborative relationships occur in the Tucum Network has made it possible to identify obstacles to be solved and successes to be strengthened, which may contribute to the strengthening of tourism in these communities.

Keywords: Collaborative Relationships. Community-based tourism. Network. Tucum Network.

Cite como

American Psychological Association (APA)

Urano, D. G., \& Nóbrega, W. R. de M. (set./dez. 2020). Community-based tourism and networks: an analysis of the collaborative relationships in the Tucum Network, Brazil. PODIUM Sport, Leisure and Tourism Review, São Paulo, 9(3), 408-434. https://doi.org/10.5585/podium.v9i3.15916. 


\section{TURISMO DE BASE COMUNITÁRIA E REDES: ANÁLISE DAS RELAÇÕES DE COLABORAÇÃO NA REDE TUCUM, BRASIL}

\section{Resumo}

Objetivo do Estudo: Buscou-se com a pesquisa analisar as relações de colaboração entre os membros da Rede Cearense de Turismo Comunitário - Rede Tucum, com base nos níveis de colaboração de Tolkach, King \& Pearlman (2013).

Metodologia: Os dados foram coletados por meio de pesquisa documental e entrevistas com 62 atores. A abordagem da pesquisa é qualitativa e os dados obtidos foram analisados por meio de uma adaptação da análise de conteúdo.

Originalidade/Relevância: A pesquisa é relevante porque os estudos sobre redes de turismo de base comunitária se concentram principalmente em propor uma abordagem de rede para fortalecer as iniciativas de turismo de base comunitária ou no papel, estruturas e organizações dessas redes. Há pouca ênfase na compreensão das relações colaborativas entre os nós da rede e os impactos dessas relações no desenvolvimento do turismo e no sucesso das redes.

Principais resultados: Os resultados obtidos mostraram que o primeiro nível de colaboração é influenciado tanto pela formação dos laços comunitários como por fatores externos à comunidade. No segundo nível, identificou-se a atuação das organizações não governamentais como elo de sustentação entre as diversas comunidades, pois estimulam as conexões entre as iniciativas de turismo de base comunitária. Por último, no terceiro nível, o processo de colaboração entre os integrantes da Rede encontra-se enfraquecido, principalmente, devido às barreiras no processo de comunicação e à falta de recursos enfrentada pela Rede e pelas comunidades, causando a desarticulação das conexões.

Contribuições Teóricas / Metodológicas: Uma compreensão mais profunda de como ocorrem essas relações de colaboração na Rede Tucum, permitiu identificar entraves a serem solucionados e acertos a serem potencializados o que pode contribuir para o fortalecimento do turismo nessas comunidades.

Palavras-chave: Relações de Colaboração. Turismo de base comunitária. Redes. Rede Tucum.

\section{TURISMO DE BASE COMUNITARIA Y REDES: ANÁLISIS DE LAS RELACIONES DE COLABORACIÓN DE LA RED TUCUM, BRASIL}

\section{Resumen}

Objetivo: La investigación buscó analizar las relaciones de colaboración entre los miembros de la Red de Turismo Comunitario Cearense (Red Tucum), con base en los niveles de colaboración de Tolkach, King \& Pearlman (2013).

Método: Los datos fueron recolectados a través de investigaciones documentales y entrevistas com 62 actores. La aproximación fue cualitativa y los datos obtenidos se analizaron mediante una adaptación del análisis de contenido.

Originalidad/Relevancia: La investigación es relevante porque los estudios sobre redes de turismo comunitario se centran principalmente en proponer un enfoque de red para fortalecer las iniciativas de turismo de base comunitaria, o en el papel, estructuras y organizaciones de estas redes. Hay poco 
énfasis en la comprensión de las relaciones de colaboración entre los nodos de la red y los impactos de estas relaciones en el desarrollo de el turismo y en el éxito de las redes.

Resultados: Los resultados obtenidos mostraron que el primer nivel de colaboración está influenciado tanto por la formación de lazos comunitarios como por factores externos a la comunidad. En el segundo nivel, el papel de las organizaciones no gubernamentales se identificó como un vínculo entre las diversas comunidades, ya que estimulan las conexiones entre las iniciativas de turismo basadas en la comunidad. Finalmente, en el tercer nivel, el proceso de colaboración entre los miembros de la Red se debilita, principalmente debido a las barreras en el proceso de comunicación y la falta de recursos que enfrentan la Red y las comunidades, lo que hace que las conexiones se desarticulen.

Contribuciones teóricas / metodológicas: Una comprensión más profunda de cómo se producen estas relaciones de colaboración en la Red Tucum permitió identificar los obstáculos a resolver y los éxitos para aprovechar, lo que puede contribuir al fortalecimiento del turismo en estas comunidades.

Palabras clave: Relaciones de Colaboración. Turismo de base comunitaria. Redes. Red Tucum.

\section{Introduction}

Community-based tourism (CBT) is considered to be a new model of tourism, different from mainstream model, that seeks to place the local community at the center of tourism development and management, as well as maintain sustainability and the distribution of benefits at the forefront of the activity (Maldonado, 2009; Coriolano, 2009; Castro \& Pinto, 2013). This model emerged as a response to the demands of communities seeking to become active actors of development by participating in all stages of tourism implementation (Cabanilla, 2015).

The benefits of CBT have been advocated by many scholars, organizations, and communities. However, these initiatives have been struggling to survive over time due to many factors, such as lack of technical qualification, lack of management skills, access to public services and basic infrastructure (Moraes, Irving \& Mendonça, 2018); insufficient profit generation; insufficient market demand; limited capacity on the part of community residents to participate in tourism development; heterogeneity of a community; complex power relations within the community and with external actors; and over-reliance and longterm dependency on external actors (Tolkach, King \& Pearlman, 2013).

To overcome these obstacles, various CBT initiatives, that have emerged since the 1980s in Latin America, have formed networks as a strategy to strengthen CBT and to resist the mainstream tourism model (Barbosa, 2011; Moraes et. al, 2018). Moraes, Irving and Mendonça (2018), for instance, identified 16 networks of CBT initiatives, which are linked 
to the Community Tourism Network of Latin America (Rede de Turismo Comunitário da América Latina - REDTURS). These CBT networks were created between 1993 and 2009, and are located in Argentina (3), Costa Rica (1), Brazil (2), Nicaragua (1), Ecuador (3), Bolivia (2), Mexico (2), Honduras (1), and Chile (1). These network articulations have been important to influence public policy agendas and to design forms of commercialization of CBT (Moraes et. al, 2018).

Despite the importance of these networks for the development of CBT initiatives, research on this specific topic is very limited. In a bibliometric study on CBT research from 2013 to 2018, Graciano and Holanda (2020) identify six main theoretical topics addressed by research on CBT: (i) local population's participation; (ii) sustainability; (iii) governance, networks and cooperatives; (iv) responsible tourism; (v) planning; and (vi) commercialization and market access. Although 'networks' is identified as one of the main research topics (together with governance and cooperatives), most of these studies focus on network collaborations within the communities (Burgos \& Mertens, 2015; Hwang \& Stewart, 2016; Burgos \& Mertens, 2017). Little attention has been given to the CBT networks formed by different initiatives. Besides, the short number of researches addressing these CBT networks has focused mainly on proposing a network approach to strengthen CBT initiatives (Tolkach et. al, 2013, Tolkach \& King, 2015; Urano, Siqueira \& Nóbrega, 2016); or the role, structures, and organizations of these networks (Barbosa, 2011; Borges, 2011; Moraes, Irving \& Mendonça, 2018). There is a lack of research focusing on the understanding of the collaborative relationship among network's nodes, and the impacts of these relationships on the development of CBT and on the success of the networks.

In this sense, it is important to address this gap regarding CBT networks in order to contribute, not only with the theoretical knowledge on CBT, but to contribute to the success of theses networks. By gaining a deeper understanding of these collaborative relationships, it is possible to identify problems which may be undermining the work done by the networks and identify ways to improve the connections among the nodes.

Considering the above, the objective of this paper is to understand the collaborative relationships among the nodes of a CBT network. The study analyzes the Community Tourism Network of Ceará (Rede Cearense de Turismo Comunitário - Tucum Network), which is a product of the articulation of several CBT initiatives that have emerged over the last two decades along the coast of Ceará in northeastern Brazil. 
To achieve this purpose, this paper is structured in five sections. First, it is presented the network theoretical framework used in the analysis. Then, it is discussed communitybased tourism networks and what collaboratives relationships they comprise. Next, the methodological path applied in the research is described. The paper ends with the results of the analysis of the collaborative relationships of Tucum Network, followed by the conclusion, which presents the limitations and suggestions for further research.

\section{Social networks approach}

The notion of network has been re-signified over the years and applied in various areas of knowledge to explain and understand biological, territorial, and social structures. Within the social sciences, the network approach has been useful to understand and analyse different forms of social relations.

Social networks are communication networks (Capra, 2002), which comprise a finite set of nodes (e.g. individuals, institutions, or communities), that establishes specific social bonds or connections (Burgos \& Mertens, 2015; Tolkach et. al, 2013). These connection processes will be different at different levels and dimensions. They occur through communication that will involve multiple aspects inherent to the human condition (Capra, 2002; Castells, 2013). The social network regenerates with each communication established. Once the communication is established, thoughts and meanings are produced in the minds of people. When communication is recurrent, a feedback process is created, which builds a common system of values, beliefs, and worldview, denominated by Capra (2002, p. 86), "a common context of meaning". This "common context of meaning" makes it possible to each individual to acquire an identity as a member or node of the network, which establishes a limit for the network, based on the individual's feeling of belonging and loyalty, which will always be renewed through new communications (Capra, 2002).

Therefore, social networks are built upon its connections, and these connections are the communication established between the nodes. It is the communication between them that will allow the consolidation of values and meanings that will guide and coordinate the construction of interdependence bonds between the parties in synergy and balance, which occurs in a non-linear organization pattern (Capra, 2002). In this sense, there is a process of self-regulation and self-organization, which emerges from the relationships built in the connection process made through communication (Capra, 1996). 
Despite this horizontal and decentralized organization and the capacity for selforganization, social networks are not detached from power relations (Capra, 2002; Castells, 2013). Communications relations are always power relations which will depend on the material and simbolic capital of each actor involved in the process (Bordieu, 1989). In this sense, the relationships established between the nodes of the network will be permeated by a symbolic struggle to affirm a worldview in which power will materialize itself through the construction of the common context of meaning and feeling of belonging established through communication.

The study of networks presupposes that individuals do not act in isolation, but that their behavior is highly affected by the relationships that are established (Scott, Cooper \& Baggio, 2008). Therefore, to comprehend the operation and outcomes of networks, it is essential to understand the relationships among their nodes.

\section{Community-based tourism networks}

CBT networks are social networks formed by communities and institutions, which seek to strengthen community-based tourism initiatives and overcome deficiencies by exchanging experiences and collective projects. They are social networks of counterpower (Castells, 2013), which are intentionally constituted with the purpose of building and strengthening collective actions that will confront the interests embedded in social institutions.

CBT networks are very diverse in their process of formation, organization, and roles. The form of organization may vary according to individual and collective interests, involving economic and political dimensions (Moraes et. al, 2018). However, they prioritize collective actions through a more horizontal, non-linear, and decentralized form of organization (Urano et. al, 2016). Their roles comprise strategic actions to enhanced commercialization and management; collective learning through exchange of experiences, resources, and knowledge; and fortification of local capacities and social mobilization to influence the formulation and implementation of public policy (Moraes et. al, 2018).

CBT networks can involve three levels of collaboration: (i) the first level occurs within the community; (ii) the second, among communities and external partners; and (iii) the third level, among communities (Tolkach et al, 2013). All these collaboration levels must be considered, both in the formation and organization stages, and also in the analysis 
of the CBT networks, so that, at each level, the network can establish a communication process and relationships that enable the creation of a common context of meaning, which is based on the principles of CBT. The network should also allow the various nodes involved to build a sense of identity and belonging, as members, to strengthen the network (Capra, 2002).

\subsection{First level of collaboration}

The first level of collaboration comprises the relationships within the community. Therefore, it is essential to understand the concept of community. For Tönnies (2004), a German sociologist who discusses the dichotomy between community and society, community (which he calls Gemeinschaft) is a life together that is real and organic, intimate and private. It is built on a natural condition of unity of human wills.

According to the author, a community can develop in three distinct instances: by blood ties, by spatial approximation and by intellectual approximation. All three types of community connections are closely interrelated over time and space, and allow us to understand the roots of all organic relationships among human beings.

In the Gemeinschaft by blood, people of the same family form organic relationships of love and understanding because they have blood ties. In the community by spatial approximation (Gemeinschaft of locality), people who live in the same location create relationships of companionship and understanding by sharing a common habitat. Although this relationship is based on spatial approximation, it can persist when a member is distant from the locality if it has as a foundation and well-defined habits of meetings and customs. Finally, in the community by intellectual approximation (Gemeinschaft of mind), relationships are created from friendship bonds, common interests or common beliefs. These relationships are created and can only be maintained through frequent physical proximity. This form of community, different from other forms, possesses a mental nature, rather than a physical nature. It is less instinctive and it is built based on free choice; therefore, must find a balance between the common will and a high degree of individual freedom.

Society (denominated Gesellschaft), in turn, is the relationship between people as an imaginary and mechanical structure. It is an artificial construction of a set of individuals who are independent from each other. In society, individuals are isolated and there is tension 
between them. There is no natural will to relate to one another, but rather a rational will to build relationships through agreements. In other words, there is a need to relate because of specific interests (Tönnies, 2004).

For Bauman, community understanding is based on homogeneity, which begins to fade with the arrival and advancement of means of transportation and computer science. In liquid modernity, there is a decadence of community life. The fluid environment disintegrates the bonds built between people in the most different forms and weakens the formation of a common will. Every unit then begins to be necessarily built. Natural understandings become 'artificially produced' agreements. In contemporary times, the real, existing communities are not communities of dreams which are formed from tacit, natural and common understandings and bring a sense of security, but rather they increase fears and insecurity. The feeling of community is not maintained, and only exists through a daily imposed quest.

The meaning of community in the world of individuals has lost its natural essence (Bauman, 2003). In this sense, it is possible to reflect on some difficulties in the conception and execution of community projects in contemporary societies. Many are weakened when obstacles appear and by internal conflicts. They need to constantly advocate against external influences to affirm their internal commitments and to reinforce the need to remain united.

Within the communities which develop CBT initiatives, there are different groups, that even though share some kind of community ties (blood, locality or mind), may have different interests that will need to be addressed when regarding an issue that will impact the whole community, such as the tourism activity. Therefore, the success of the collaborative relations will depend on the level of appropriation of the project by the community, the social structure of the community and the power imbalances (Tolkach et al, 2013; Burgos \& Mertens, 2015). These aspects will vary according to the particularities of each community.

\subsection{Second level of collaboration}

At the second level, collaborative relationships among communities and external partners take place. These collaborative relationships are important to support the development of CBT initiatives through sources of funds, expertise and new information. 
These external partners may be institutional advisory services, public authorities, academia, tour operators and non-governmental organizations (NGOs). It is important to emphasize that, depending on the network structure, these partners may or may not be formally part of the network.

Such partnerships are essential to meeting community needs, such as lack of basic infrastructure, product promotion and marketing, provision of community-based tourism data, technical advice and (in some cases) financial resources. However, it is worth noting that the network must be established from a natural process based on trust and not from an imposition of these external agents. The community must be the key element of the network and must play the leading role (Tolkach et al., 2013). Therefore, it is essential that the network works towards building a balance that allows the autonomy of the subjects involved.

In addition, Tolkach et al. (2013) point out that CBT is experiencing a conflict as a model of tourism management and planning, given that it combines both commercial operations and community development, which creates conflicts of interest between the objectives of the community and the external actors.

\subsection{Third level of collaboration}

At the third level, in which solidarity bonds among communities are established, connections are created that enable the network to integrate. The various communities that form these networks have some common aspects, which allows the creation of bonds. However, they are in their essence heterogeneous and, thus, can be based on different models of community organization or different perspectives of CBT (Tolkach et al., 2013).

Given the diverse experiences among members of the CBT networks, relationships of collaboration are built through a process of communication and knowledge exchange as well as an exchange of experiences and struggles that give life to the network. This communication process aims to strengthen community organization and CBT development within each community. With the strengthening of the community organization, a feedback loop is created, which further strengthens the network and, consequently, the communities, in a cyclical pattern. Similarly, if there is a weak node in the network, a negative feedback process occurs, which can weaken the reticulate structure of the communities. 
Therefore, it is necessary to create communication processes that are constantly fed back (Capra, 2002; Castells, 2013) to build a sense of collaboration among the initiatives and, thus, enable mutual aid among the nodes.

\section{Methodology}

The objective of this study is to understand the collaborative relationships in the Tucum Network, which is the result of the articulation and connection of CBT initiatives located in the coastal region of Ceará State, northeast of Brazil. Tucum Network is currently composed of fifteen community-based tourism initiatives: Coqueirinho - Municipality of Fortim; Maceió Settlement - Municipality of Itapipoca; Batoque - Municipality of Aquiraz; Caetanos de Cima - Municipality of Amontada; Frei Humberto Training Center and Research from Movimento Sem Terra (MST) - Municipality of Fortaleza; Conjunto Palmeiras - Municipality of Fortaleza; Curral Velho - Municipality of Acaraú; JenipapoKanindé - Municipality of Aquiraz; Flecheiras - Municipality of Trairi; Prainha do Canto Verde - Municipality of Beberibe, Ponta Grossa - Municipality of Icapuí; Tapeba Municipality of Caucaia, Tatajuba - Municipality of Camocim; Tremembé - Municipality of Icapuí; and Vila da Volta - Municipality of Aracati. Tucum also counts on the institutional support of three non-governmental organizations (NGOs): Caiçara Association, Terramar Institute, and Adelco.

Data collection was conducted through documentary research and face-to-face interviews, and it was carried out between August of 2015 and March of 2016. The documentary research was used as a complementary technique for deepening the data obtained through interviews and field observations. The selection of relevant and available material for documentary research was carried out with the Tucum Network's secretariat. The General Assembly's records of the years 2014 and 2015, as well as Tucum Network's Norms and Procedures Book (Caderno de Normas e Procedimentos da Rede Tucum) were selected.

Face-to-face interview was chosen as the main data collection technique due to its flexibility in obtaining information from individuals, as it is possible to achieve great depth and establish a much greater bond with the interviewee (Haymann, 1973). Four communities were selected for this phase: Jenipapo-Kanindé, located in the municipality of Aquiraz, which is an indigenous village; Prainha do Canto Verde, located in the municipality of Beberibe; 
Coqueirinho, a rural settlement located in the municipality of Fortim; and Ponta Grossa, a fishing community located in the municipality of Icapuí, which has a more consolidated flow of tourists. They were selected based on the Tourism Macroregions of Ceará State, Brazil. The Macroregion of the East Coast was chosen because of the intense flow of tourists, greater urbanization of the coast, and because it is the region where the first CBT initiatives in the State began.

Research participants were chosen based on an intentional sample, in which a small group of people is chosen according to the criterion of social representativeness (Thiollent, 1997). Therefore, interviews were conducted with one representative of the Local Tourism Group (LTG) of each community selected for this research; one representative of each NGO, that gives institutional support to Tucum Network; one representative of each municipality government; and representatives of the local population. The sample for the local population was random and by adherence and included both members and non-members of the LTG. A total of 62 people was interviewed (Table 1). Interviews were carried out during visits to each selected community, NGOs and the Secretary of Tourism of Aquiraz, Fortim, Beberibe and Icapuí. All interviews were recorded and fully transcribed.

Table 1 - Research participants

\begin{tabular}{clc}
\hline Actors & Description & Number of Interviews \\
\hline \multirow{3}{*}{ Secretary of Tourism } & Aquiraz & 2 \\
& Beberibe & 1 \\
& Fortim & 1 \\
& Icapuí & 1 \\
\hline Non-governmental & Adelco & 1 \\
Organizations & Associação Caiçara & 1 \\
(NGOs) & Instituto Terramar & 1 \\
\hline \multirow{3}{*}{ Local Tourism Group } & Jenipapo-Kanindé & 1 \\
(LTG) & Prainha do Canto Verde & 1 \\
& Assentamento Coqueirinho & 1 \\
& Ponta Grossa & 1 \\
\hline \multirow{2}{*}{ Local Population } & Jenipapo-Kanindé & 13 \\
& Prainha do Canto Verde & 10 \\
& Assentamento Coqueirinho & 14 \\
\hline & Ponta Grossa & $\mathbf{6 2}$ \\
\hline
\end{tabular}

Source: Research data. 
An adaptation of content analysis (Godoy, 1995; Bardin, 2004) was applied to analyze the data obtained on both documentary research and interviews. The interviews were fully transcribed and read. Then, it was possible to codify and aggregate the data into categories. The data were categorized according to the levels of collaboration in CBT networks presented by Tolkach et al. (2013). At each level, some categories were defined as shown in the results below.

\section{Results and discussion}

\subsection{First level of collaboration - relationships within the community}

The analysis of the first level of collaboration considered the formation of the community ties to understand the relationships among its members as well as the social relations that emerged with the development of CBT. In order to understand the community's ties, a brief history of the formation of the communities is presented.

Jenipapo-Kanindé community is located on the banks of Encantada Lagoon, in the municipality of Aquiraz, 50 kilometers from Fortaleza, the state capital of Ceará. The community is made up of approximately 336 inhabitants, both indigenous and non-indigenous, who live primarily of family farming, pastoral activities, and fishing. The production of handicrafts and tourism activities provide complementary income.

In 1984, the community formed its first association to strengthen the struggle for the right to land. At that time, the issue of indigenous ethnicity was an essential element to mobilize the community around common causes, such as real estate speculation. During this period, the community suffered threats from land-grabbers and the attempt to build a tourist enterprise.

In 1999, a political body of the ethnic group was formed. Jenipapo-Kanindé Indigenous Council was a result of the community's struggle for ethnic recognition and for their indigenous lands to be rightfully declared so. In 2002, internal conflicts led to the creation of JenipapoKanindé Association of Indigenous Women (Antunes, 2008). The process to formally declare indigenous lands was initiated in 1997 by the National Indian Foundation (Fundação Nacional do Índio - FUNAI), and on February 24, 2011, their lands were formally recognized with 1,731 hectares.

The community tourism organization was founded on a project carried out by the Federal University of Ceará, called "Trilha do Índio". The Project lasted a year and six months, 
between 2005 and 2007, and consisted of mapping trails and training local people to guide visitors. Five trails were developed during the project and after the project ended the community continued to run it by mainly receiving school groups, including university students, teachers, and researchers. Currently, the community offers to its visitors five trails as well as lectures about the community and visits to the Indigenous Museum, the Indigenous School and the House of Flour (the place where manioc (Manihot esculenta) is transformed into flour). Food and lodging are also offered at the Community Inn.

The Local Tourism Group (LTG) consists of approximately 20 participants, who do not work every day, but only when they have a large group. Visitor flow is not regular and needs to be induced so that it can occur more frequently and benefits more families. Thus, there is no collective understanding of the benefits that tourism can bring to the community, since few people directly participate in the activity, which creates some conflicts among the residents.

Following Tönnies' (2004) understanding of community, it can be perceived that Jenipapo-Kanindé is formed mostly by blood, spatial and intellectual approximation ties. Despite the existence of internal conflicts, the community has a strong organization that led to the demarcation of lands and the recognition of indigenous ethnicity in the community. These existing conflicts have not yet damaged community organization, mainly due to the strong presence of Cacique Pequena's leadership.

When developing a CBT initiative, one of the internal challenges is to connect more people in the community in order to benefit a larger part of the population and, thereby, expand the construction of a common context of meaning in relation to tourism and boost collaborative relationships. Despite having an active LTG, the community has not been able to mobilize new participants to enter the tourism network, thereby making it difficult to build a collective will for CBT and potentially jeopardizing the organization process and the continuity of LTG.

Prainha do Canto Verde (PCV) is located in the municipality of Beberibe, $120 \mathrm{~km}$ from Fortaleza, the capital of Ceará State and has a population of approximately 1,100 inhabitants. Since 1979, the community has struggled with conflicts over land. In 1989, the Association of Prainha do Canto Verde Residents (Associação de Moradores da Prainha do Canto Verde AMPCV) was established with the primarily goal of defending the land and interests of residents from real estate speculation.

In 1994, residents of the PCV began to discuss the future of their community, given that, at the time, the only and almost exclusive form of income-generating activity was fishing, 
followed by low-water subsistence farming. They began to question how the community could work together to develop tourism, since tourism activities had already reached nearby beaches and tourism could potentially reach the PCV soon. The question was how the community could be an active agent of this process.

Thus, a common context of values was built for tourism, whereby the community would be the active agent of the tourism development process, i.e., owner and manager of the projects. Initially the population began receiving people in their homes, including representatives from NGOs and universities who were working in the community. Later, residents began to organize themselves to build the first inns and chalets. In 1998, the Community Tourism Council was created to oversee matters related to community tourism. The council is formed of residents who are involved in tourism activities, such as people who own lodges, chalets, houses for rent, or who are involved in tourism in some way.

The LTG is linked to the Tourism Council, which is attached to AMPCV. Each enterprise pays a 10\% rate on top of its tourism profit to the LTG. Between 1998 and 2009, the LTG was able to engage everyone involved in the tourism industry in the community and there was a collective understanding of the type of tourism that the community wanted to develop.

The struggle for territory led to the creation of the Extractive Reserve (Reserva Extrativista - RESEX) of Prainha do Canto Verde in 2009. The RESEX covers both a marine area and a continental area. With the creation of the RESEX, a new conflict arose over land in the community, when an entrepreneur claimed ownership of 50\% of the RESEX area and went to court to request that the reserve be cancelled. The influence of the entrepreneur also divided the AMPCV. The Independent Association of Residents of Prainha do Canto Verde (Associação Independente dos Moradores da Prainha do Canto Verde - AIMPCV) was, then, created. It has 370 members and is against the RESEX on the mainland.

With the creation of the RESEX, the community was divided into two diverging groups: those who support the extractive reserve and are focussed on the socio-environmental sustainability of the community, and those who do not support the mainland reserve and view development in terms of economic aspects. This conflict has been interfering with the process of community organization and could affect CBT activities in the future.

Over the last two decades some of the people that were part of the LTG have left and started to operate individually. Currently, only some of the lodges and chalets are part of the LTG and the Tucum Network. The other enterprises are from people in the community, but 
they operate individually, rather than under the community-based tourism network, and they may be member or not of AIMPCV.

In this sense, Prainha do Canto Verde's community organization has started to dismantle, which has already influenced the LTG in a negative way and some members have left. This issue could persist and worsen if there is no collective mobilization and reconstructive actions devoted to tourism.

Coqueirinho Rural Settlement was constituted on August 23 $3^{\text {rd }}, 1995$ in the municipality of Fortim, which is located $135 \mathrm{~km}$ from Fortaleza. Initially the area received 14 families from the municipality of Fortim and nearby municipalities. Currently, there are 60 families living in the community, totalling around 400 inhabitants. Community residents mainly earn an income from family farming, animal husbandry, social programs from the Brazilian Federal Government, pensions, and from work outside the settlement such as working for private companies or for the Goverment.

In 1996, the Cooperative Association of the Coqueirinho Settlement Project (Associação Cooperativista do Projeto Assentamento Coqueirinho - ACOOPAC) was created. Due to internal divergences, members split and the Association of Individual Members of the Coqueirinho Settlement (Associação dos Parceleiros Individuais do Assentamento Coqueirinho - APIAC) was founded. Later, due to divergences on the issue of deforestation, there was a second division and the Association for Autonomous Members of the Coqueirinho Settlement (Associação dos Parceleiros Autônomos do Assentamento Coqueirinho - APAAC) was formed. APIAC, in turn, also suffered a division when a fourth association was founded. Currently, there are four associations working in the settlement. The productive system is fragile, with poor soil productivity and dependent on the rainy season. Therefore, the scarcity of rainy periods in recent years has been further making it difficult agricultural production.

In 2004, Tremembé Onlus Association, from Italy, along with Caritas and Caiçara Associations, came together to discuss with the community ways for these families to continue to sustain their livelihoods on the settlement in a sustainable way. At the time, communitybased tourism was considered as an alternative. Thus, the community executed projects such as the community vegetable garden and the construction of four chalets to receive visitors, which was financed by Tremembé Onlus. The settlement began to receive groups of Italian tourists, student groups, associations, NGOs, and social movements. In the later years, two more chalets 
and two restaurants were built, and several projects were created within the community, such as cosmetics production, Coqueirinho Visual Audio Nucleus, and a theater group.

The LGT is currently associated with ACOOPAC and has approximately 12 families. The LGT meets only when it receives groups of tourists. Coqueirinho Settlement joined the Tucum Network during its creation in 2008.

Currently, some community projects are not operating, such as the vegetable garden, the Coqueirinho Visual Audio Nucleus, the production of cosmetics, and theater and cultural nights. One of the factors that led to the suspension of these projects was a decrease in the flow of tourists, especially the number of foreign tourists. The current flow of tourists is mainly represented by groups of students and there has been a very large decrease in the total amount of tourists. The absence of a constant flow of tourists weakened the LTG and some members of the group left.

Another contributing factor that the community has faced is the difficulty in getting young people to stay in the settlement, given the lack of employment and income opportunities. Young people departing from the community impairs the construction of community tourism and is, therefore, both a cause and a consequence of the weakening of the LTG. Without the youth, some activities have stopped, thereby reducing the attractions offered to tourists. Without the young people, the LTG is unable to continue, nor develop. This presents an obstacle to the development of CBT in the community.

Another factor that hinders the development of local tourism and has been weakening the LTG is the existing conflict between associations in the construction of values and meanings. Perceptions and beliefs surrounding the community way of life and preservation of the environment are different, which makes it impossible to build a collective will; an essential component to build CBT.

It was noticed in the testimonies that the community failed to construct a common context of meaning, i.e., a set of similar values and a similar worldview among the residents of the settlement. The conceptions of development diverge within the community. Part of the community believes in a development based on sustainability, the preservation of the environment and the empowerment of the local population, whereas another part of the community believes that development has to do with immediate benefits. Despite the conflicts encountered, LTG members still consider the CBT to be positive and perceive the need to 
stimulate tourism, so that it can mobilize and aggregate more people from the community and, thus, strengthen the LTG.

With a weakened LTG, the community cannot contribute to strengthen the Tucum network. On the contrary, it ends up distancing itself from the Network by failing to participate in formations, meetings and assemblies, which makes it even more difficult to strengthen CBT in the community. Another point to be highlighted is that the community's ties in Coqueirinho are mainly spatial since the community was formed by different families and there is no intellectual approximation.

The community of Ponta Grossa is located in the municipality of Icapuí, on the east coast of the State of Ceará, roughly 210 kilometers from the capital city Fortaleza. It comprises around 64 families, with a total population of approximately 250 inhabitants. Most of the population is part of the same family, the Crispim family. It is a traditional seaside fishing community.

Ponta Grossa has also suffered from conflicts over possession of its lands, which culminated in the need for community organization to defend its territory. In 1993, the Ponta Grossa Residents' Association was created to defend the rights of residents, especially in matters related to the right to land tenure.

Ponta Grossa has strong community ties, in all three categories presented by Tönnies (2004): blood ties, since the majority of the population is part of a single family; spatial proximity, which becomes more consistent from the fight and the conquest of its territory; and intellectual closeness, since this is an essentially evangelical community, thus sharing the same beliefs and values.

The community was inserted into the tourist route with the arrival of buggy tours from Canoa Quebrada beach, located nearby. As demand grew, access roads were built, and real estate speculation increased. Therefore, residents began to mobilize to develop tourism according to their principles, in order to meet the needs of the entire community. It was in this context that the Tourism, Environment and Culture Association of Ponta Grossa (Associação de Turismo, Meio Ambiente e Cultura de Ponta Grossa - ASTUMAC) was created in 1998, which is the Local Tourism Group. ASTUMAC is currently made up of approximately 35 active members, which includes beach restaurants, inns, snack bars and tour guides. Its purpose is to articulate decisions regarding the installation of new businesses, infrastructural improvements and services offered. All tourism ventures are family owned and operated by the community. 
Land ownership is collective, and each family has their own defined space within the community where they can build. There is also a designated space to build tourism equipment.

The local community organization is strong since there is a collective effort among the local population to maintain the beach with its traditional way of life and preserve the local culture and environment. Thus, tourism is developed with the effective control by the community. It is the community who decides the direction that tourism will take. According to the LTG representative, this is because there is a sense of belonging among residents that fosters union and collective will to preserve what they have already conquered.

\subsection{Second level of collaboration - relationship with NGOs}

At the second level of collaboration, the role of NGOs and community's autonomy were analysed. It is important to highlight that the analysis of the second level of collaboration in this study focused on the relationship among communities and NGOs. Interviews with the government representatives were conducted to understand the government role on the development of the CBT initiatives, and to confront the communities and NGOs' perception.

Since its inception, Tucum has worked with NGOs that provide institutional advice. There are currently three NGOs: Instituto Terramar de Assessoria à Pesca (Terramar), Associação Caiçara de Promoção Humana and Associação de Desenvolvimento Local CoProduzido (Adelco). Terramar is a non-profit, non-governmental organization located in Fortaleza and created in 1993. Its social objective is to contribute to environmental justice in the Coastal Zone of Ceará. Terramar had already been working with the twelve communities before the Tucum Network was formed. It currently advises communities located on the West coast within the Network.

The Caiçara Association is an entity in the municipality of Icapuí that mainly works with community tourism projects. It was founded in 2000 and one of its first projects was the construction of an inn in the community of Tremembé, Icapuí, in partnership with the Italian institution Tremembé. Part of the inn's profits is reverted to Caiçara. Within the Network, Caiçara advises the communities on the East coast.

Adelco is a non-profit entity located in Fortaleza. It was founded in 2001. It works mainly with the indigenous ethnic groups of Ceará and advises the indigenous communities in the network: Tapebas and Jenipapo-Kanindé. 
The work of NGOs in the communities reveals another social actor in the configuration of the CBT: the third sector. The performance of this sector as a social actor of tourism has been growing in recent years, accompanying the process of discussions about the impacts of conventional tourism and the need for new forms of tourism organization. Its main functions are to build awareness, to help communities organize, to articulate the elaboration of new tourism practices, to train the local population and to fundraise projects.

Tolkach et al. (2013) emphasize that the network must be established from a natural process based on trust and not from an imposition of external agents. The community should be the key element of the network and should play the main role. However, external actors play a key role in training and fundraising.

The purpose of these advisory services in the Tucum Network is to create an environment in which communities can be autonomous in the process of local development and community organization. However, this seems to be a long-term goal. Many communities still rely heavily on the functioning of LTGs.

Some communities are already able to stand out, walk alone; others do not, they still have a certain dependence, they need advice, they need an entity, they need a concrete project to be able to maintain. (...) some still have this dependence. Unfortunately, we are a network that still cannot stand on our own feet (Caiçara Representative).

The reliance that some communities have on the support of the NGOs is an obstacle to the CBT development, both because it limits their autonomy and because the NGOs lack financial and personal resources to provide better assistance. This ends up harming the most dependent communities impeding community organization and, therefore, community empowerment.

It should be noted that within counterpower networks there are always stronger nodes that have greater influence to negotiate and to propose actions, thereby mediating the organizational process. According to Scherer-Warren (2006), this mediation process is often considered relevant to empower social movement networks. The NGOs within Tucum act as mediators. It is essential, however, that the network works to find a balance that allows the community's autonomy despite the existence of mediators.

For the NGOs, the issue of community autonomy is essential for the Network to continue its work independently, as can be seen on the following testimony: 
Autonomy is an important issue for us because if we do not have autonomy locally, community tourism will not work, and other things will not work. I think the debate on autonomy and the creative freedom of groups is very important. There are some agreements that are created not to limit the creativity of communities and autonomy, but rather to try and make sure that people do not lose focus of the purpose of the network. (Terramar Representative)

LTGs should build the CBT process within communities and then promote to the rest of the Network. However, as many communities are still structuring themselves in strengthening the community organization for tourism, the issue of community autonomy within the Network is compromised. The communities alone are unable to make the Network work and need strong support from the consultants.

Another problem encountered by the NGOs is the lack of continuity among residents in the groups. Some people who participated in the first formations at the beginning of the Network have since left the LTGs. It was also noticed that the LTGs were mainly formed by adults and with little participation among young people. One of the strategies designed to overcome this obstacle was the creation of the Popular School of Community Tourism, which was designed to bring adolescents and young adults together to discuss territory, work and community tourism in order to mobilize more people to participate and bring life to the LTGs.

\subsection{Third level of collaboration - relationship between communities}

Regarding the third level of collaboration, the communication process, the influence of first level of collaboration and resource sharing were the main aspects analysed.

It was identified that in the Tucum Network, connections between the communities were established from the struggles over land and the affirmation of identity suffered by each community. The debate on the importance of guaranteeing land and the need for the local population to effectively participate in building the kind of society they seek, as well as preserving the environment, their traditional economic activities and their culture were decisive for the communication processes, described by Capra (2002) and Castells (2013), occurred between these communities. This communication process enabled the exchange of experience and knowledge, and it has made it possible to build a common context of meaning surrounding CBT development and tourism. 
The communities had already contact with tourism, albeit at a basic level, and saw it as a strategy to defend their land and affirm their cultural identity, in addition to a way of complementing their income. However, they recognized the need for effective social participation in the tourism development process, i.e., the need to be active agents in this process to control the socio-spatial transformations of the place where they live (Bordenave, 2007). As a result, each community organized a collective action regarding tourism development.

The collaborative relationships among the communities were made possible and enhanced by the advisory services of non-governmental organizations who work in the coastal zone and provided the communication link between these communities. Thus, ties of interdependence were built to form the Tucum Network, which initiated a process aimed at strengthening communities, despite the differences and peculiarities among the initiatives. These differences are essential when exchanging experiences. However, they can hinder the formation of a common context of values and meanings of tourism within the Network, given that, as Tolkach et al. (2013) advocate, there are different organizational models and different points of view of CBT among different communities.

To address this problem, since the creation of Tucum, work has been undertaken to build a collective orientation for the development of CBT within the communities. This work culminated in the Tucum Network's Norms and Procedures Book. This document contains the principles of community-based tourism developed by the Network, as well as the guidelines for organizational structure, management strategies, financial sustainability, and organization of the tourist services offered. The notebook is not a static document and changes, based on the decisions of all members of the Network, are possible. This document is an important tool to build the common context of meaning. However, many representatives of the initiatives who participated in the construction of this document, failed to propagate it within the communities. Consequently, many members of the Network are unaware of the agreements and the document lost its importance.

Another problem regarding the differences between the communities is the level of CBT development. While some communities have already a constant flow of tourists, such as Prainha do Canto Verde and Ponta Grossa. Others, such as Coqueirinho Settlement and Jenipapo-Kanindé have been struggling to attract tourists. The lack of tourist flow results in the disorganization of the LTGs. In this sense, some communities expect Tucum to be 
able to reorganize and stimulate the LTGs, even though they perceived the LTGs as the basis of the Network, which need to be strengthened so that the networks can act. This can be seen on the following testimony:

I think the fundamental role of the LTGs is to strengthen the network... I think we have to always strengthen by unifying, so that it [the network] never ceases to exist because, if it is not us, (...) if we do not reinforce it, if we do not have the responsibility to maintain the network, I do not think it will go forward. (Jenipapo-Kanindé)

When the first level of collaboration is impaired, the communities tend to distance themselves form the network, weakening the collaborations at the third level and affecting the Network's organization and work, as it has happened in Coqueirinho:

To tell you the truth, we really are very discouraged. Here tourism has been on the rise. [Currently] few people are going to Tucum Network meetings. We didn't even participate in this year's Assembly. It's hard for us. Very difficult. (Coqueirinho Settlement)

[The Network] is weak because the network itself doesn't help [the communities], it doesn't help to pursue a strategy. Because if it were a network, the problem of one would be [the problem] of all. We are really missing this, [we are missing] to seek a strategy to attract tourists. The network is weak in my opinion. (Coqueirinho Settlement)

The LTGs are the foundation of the Network, if they are not organized and strengthened, the Network will weaken. Likewise, the Network can only be strengthened if the LTGs are well structured. This was shown in the testemonies of all communities:

For it [the Network] to work, all the groups must be together and with strength so that this network will emerge. (Coqueirinho Settlement)

The Network is the communities themselves. If the communities are strong, the Network is strong; if communities are weak, the network is weak. (Ponta Grossa)

If the communities do not organize themselves, because the organization comes from the community. Because the network is us. But the network will not be in the communities every day (Jenipapo-Kanindé)

The Tucum Network should be the communities, but this can take many years (Prainha do Canto Verde) 
Other factors, such as poor communication and lack of resources, make even more difficult the collaboration at the third level. The problem of communication is one of the main problems faced by the network, since the network arose from the connections between the different nodes, i.e., from communication processes. The social network regenerates with every communication made because, as communication is established, thoughts and meanings are produced in people's minds. When communication is recurrent, a feedback process is constructed that creates a common system of values, beliefs and worldviews, i.e., "a common context of meaning" (Capra, 2002, p.86). If these nodes fail to communicate, the whole process of building the network will collapse. The connections will weaken, thereby leading to its demise. However, the issue of communication goes beyond the network because it is mainly due to the lack of infrastructure within the communities, such as the maintenance of the cell phone tower and internet networks, which is the responsibility of the public sector.

Similarly, another obstacle arises. Given that infrastructure in these communities is very incipient, the responsibility falls on the community to solve this problem through community organization. Yet, it struggles to do so. The network has been trying to overcome this difficulty by developing projects that focus on community communication and equipment capable of meeting their needs.

Regarding the lack of resource, the network's financing system is not working. Many LTGs cannot raise enough money to share with Tucum. While other initiatives, that do raise money, sometimes, fail to share it. Thus, the network does not have enough capital to cover issues, such as: marketing, operation of the Secretariat (which serves as a tour operator and a link between coordination and communities) and the coordination itself to enhance collaboration. Often this work ends up being carried out by the NGOs, which also suffer from lack of resources.

It can clearly be inferred that the network's collaborative relationships are weak, which makes it impossible to assist communities with weak LTGs.

\section{Conclusions}

This research focused on the collaboration relationships of a CBT network, aiming to raise both theoretical and practical issues regarding this theme. The analysis was based on the three levels of collaboration described by Tolkach et al. (2013). 
At the first level of collaboration, the CBT requires that collaborative relationships be strongly established and that a collective will of values, beliefs and conceptions of development is built. It is this collective will that enable community organization and effective popular participation within the community. These collaborative relationships must go beyond tourism and, therefore, are strongly influenced by several factors, including territorial issues, social relations, political formation, basic infrastructure, cultural issues, local employment, and income opportunities. In addition, it was perceived that the collaborative relationships in communities with blood and mind ties (e.g. Jenipapo-Kanindé, Prainha do Canto Verde, and Ponta Grossa) were more successful than in communities with only locality ties (e.g. Coqueirinho Settlement). However, these community ties are changing over time and may loose strengthen when other social relations are established, such as the relations created by tourism activity, as could be seen on the case of Prainha do Canto Verde.

With regards to the second level, the work of NGOs as social actors is essential in the process of strengthening and articulating CBT in communities. They serve as mediating points that stimulate the connections between the initiatives and provide support to political formation and community organization within the LTGs. The work of these organizations is perceived to be temporary and aims to build autonomy among the communities in the network. CBT networks aims to strengthen CBT initiatives and build their autonomy in the development of tourism. However, CBT networks have been dependent on external agents in the same way as in the initiatives. Therefore, the achievement of autonomy remains an obstacle on CBT.

At the third level of collaboration, it became evident that the connections between communities were established through common links, which includes the struggle for land, identity affirmation and the development of CBT as a mechanism of resistance. Besides, it shows that the third level is influenced by the collaboration relationships of the first level. Communities which are experiencing a dismantling of the first level collaboration tend to distance themselves from the network and the third level of collaboration is affected. In addition, the process of collaboration has been suffering with barriers in the communication process and the lack of network and community resources.

It is worth noting, however, that CBT networks are very complex due to the heterogeneity of its participants. Therefore, further research is needed to deepen the understanding at each level of collaboration. In this sense, it is suggested, for the first level 
of collaboration, studies that comprise the correlation between the formation of the community ties and the development of CBT as well as the influence of external factors on theses community ties, and consequently on CBT. For the second level, studies regarding the construction of autonomy within theses communities are needed. And for the third level, it is suggested research on the communication process for building a common context of meaning within a CBT network. Besides, it is suggested research comprising other communities, members of the Tucum Network, and other CBT networks, aiming to strengthen theses initiatives.

\section{References}

Antunes, T. D. (2008). Construção étnica e políticas públicas: mobilização, política e cultura dos índios Jenipapo-Kanindé. Fortaleza: (Dissertação de Mestrado) UECE.

Barbosa, L. M. (2011). Redes de territórios solidários do turismo comunitário: políticas para o desenvolvimento local no Ceará. 160f. Fortaleza: (Dissertação de Mestrado) UECE.

Bardin, L. (2004). Análise de Conteúdo. Lisboa: Edições 70.

Bauman, Z. (2003). Comunidade: a busca por segurança no mundo atual, Rio de Janeiro, Jorge Zahar Ed.

Bordenave, J. E. (2007). O que é participação. São Paulo: Brasiliense.

Borges, C. I. (2011). O turismo comunitário em comunidades tradicionais na zona costeira do ceará: em foco a experiência da Rede Tucum. Fortaleza: (Dissertação de Mestrado) PPG-UFC.

Bourdieu, P. (1989). O poder simbólico. Rio de Janeiro: Editora Bertrand Brasil.

Burgos, A., \& Mertens, F. (2015). A perspectiva relacional na gestão de base comunitária: o caso da Prainha do Canto Verde, Caderno Virtual de Turismo, 15 (1), 81-98.

Burgos, A.; \& Mertens, F. (2017). Participatory management of community-based tourism: A network perspective. Community Development, n. 48 (4), pp. 546-565, http://doi.org/10.1080/15575330.2017.1344996

Cabanilla, E. (2015). Impactos culturales del turismo comunitario en Ecuador sobre el rol del chamán y los ritos mágico-religiosos, Estudios y Perspectivas en Turismo, 24, 356-373.

Capra, F. (1996). A teia da vida. (N. R. Eichemberg, Trad.). São Paulo: Cultrix

Capra, F. (2002). As conexões ocultas, (M. B. Cipolla, Trad.). São Paulo, Cultrix. 
Urano, D. G., \& Nóbrega, W. R. de M. (set./dez. 2020). Community-based tourism and networks: an analysis of the collaborative relationships in the Tucum Network, Brazil

Castells, M. (2013). Redes de indignação e esperança: movimentos sociais era da internet, Zahar.

Castro, L. L. \& Pinto, R. (2013). Sustentabilidade e turismo comunitário: aspectos teóricosconceituais, Caderno Virtual de Turismo, n. 13 (2), pp. 213-226.

Coriolano, L. M. (2009). O turismo comunitário no nordeste brasileiro. In: Bartholo, R., Sansolo, D. G., Bursztyn, I. (Eds.). Turismo de base comunitária: diversidade de olhares e experiências brasileira (277-288). Brasília, Letra e Imagem.

Godoy, A. S. (1995). Introdução à pesquisa qualitativa e suas possibilidade. RAE - Revista de Administração de Empresas, n. 35 (2), pp. 57-63.

Graciano, P. F.; \& Holanda, L. A. (2020). Análise bibliométrica da produção científica sobre turismo de base comunitária de 2013 a 2018. Revista Brasileira de Pesquisa em Turismo, São Paulo, n. 14 (1), p. 161-179. http://dx.doi.org/10.7784/rbtur.v14i1.1736

Haymann, J. L. (1973). Investigacion y educacion. Paidos.

Hwang, D.; \& Stewart, W. P. (2017). Social Capital and Collective Action in Rural Tourism. Journal of Travel Research, V.56 (1), pp. 81-93. http://dx.doi.org/10.1177/0047287515625128

Maldonado, C. (2009). O turismo rural comunitário na América Latina: gênesis, características e políticas. In Bartholo, R., Sansolo, D. G., Bursztyn, I. (Eds.). Turismo de base comunitária: diversidade de olhares e experiências brasileiras (25-44). Brasília, Letra e Imagem.

Moraes, E. A., Irving, M. A., \& Mendonça, T. C. M. (2018). Turismo de base comunitária na América Latina: uma estratégia em rede. Revista Turismo e Ação, n. 20 (2). http://dx.doi.org/10.14210/rtva.v20n2.p249-265

Scherer-Warren, I. (2006). Das mobilizações às redes de movimentos sociais. Sociedade e Estado, n. 21 (1), pp. 109-130. http://dx.doi.org/10.1590/S0102-69922006000100007

Scott, N, Cooper, C., \& Baggio, R. (2008). Network Analysis and Tourism: from theory to practice. Channel Views Publication.

Thiollent, M. (1997). Pesquisa-ação nas organizações. São Paulo, Atlas.

Tolkach, D., King, B., \& Pearlman, M. (2013). An Attribute-Based Approach to Classifying Community-Based Tourism Networks, Tourism Planning \& Development, n. 10 (3), pp. 319-337. https://doi.org/10.1080/21568316.2012.747985

Tolkach, D.; \& King, B. (2015). Strengthening community-based tourism in a new resourcebased island nation: Why and how? Tourism Management, n. 48, pp.-386-398. http://dx.doi.org/10.1016/j.tourman.2014.12.013 
Tönnies, F. (2004). Community and Society, New Brunswick, Transaction Publishers.

Urano, D. G., Siqueira, F. S., \& Nóbrega, W. R. M. (2016). Articulação em redes como um processo de construção de significado para o fortalecimento do turismo de base comunitária, Caderno Virtual de Turismo, n. 16 (2), pp. 200-210.

http://dx.doi.org/10.18472/cvt.16n2.2016.1173. 